\title{
Psycho-Social Pre-Retirement Plans Of Lecturers In Public Universities In Rivers State, Nigeria
}

\author{
Dr. C. Amini-Philips \\ Department of Educational Management \\ University of Port Harcourt \\ Nadum Nekabari Kinanee \\ Department of Educational Management \\ University of Port Harcourt
}

\begin{abstract}
The study investigated lecturers' psycho-social pre-retirement plans in public universities in Rivers State, Nigeria. Two (2) research questions were formulated and answered while two (2) hypotheses were tested at $0.05 a l p h a$ level. The study adopted a descriptive survey research design. The population of the study consisted of all the 2330 lecturers in the three public universities in Rivers State. As at the time of this study, each of the universities has the following population breakdown respectively: University of Port Harcourt (UNIPORT) 1500, Rivers State University (RSU) 556, Ignatius Ajuru University of Education (IAUOE) 274 making a total of 2330 lecturers from the three (3) public universities in Rivers State. (Source: Registry Department of the various institutions 2017). A sample size of 932 was used. The sample size was drawn using simple random sampling technique from the three universities in Rivers State. The instrument for the study was titled "Lecturers Psycho-Social Pre-Retirement Plans Scale" (LPSPRPS). Simple percentage was used to answer the research questions while Chi-Square statistics was used to test the null hypotheses at 0.05 alpha level. It was found among others that $46 \%$ of the lecturers agree that they have financial plans while 54\% disagree. It was recommended among others that Pre-Retirement Guidance and Counselling centres should be established in university communities where lecturers who have emotional problems can go and seek help from counsellors.
\end{abstract}

Keywords: Lecturers, Psycho-Social Pre-retirement and Plans

\section{INTRODUCTION}

The life of a lecturer on the job and after work depends on number of things; these include but are not limited to the pattern of lifestyle and social responsibilities, psychological reasoning and retirement responsibilities. The university system has it that lecturers should retire after 35 years of active service or attaining the age of 65 years in the service and 70 years of age for the full professorial status. Operationally, lecturers are faced with two major challenges at retirement; these are psychological adjustment and social adjustment.

The social adjustment problem is a serious one that makes a retiree to visit other work place after retiring from active service. Some lecturers are not prone to making friends outside the university community while in employment hence find it difficult to adjust outside the university environment after retirement. Some of them prefer to stay indoors since they were unable to make friends outside the community of lecturers. Those who were able to socialize both in the university environment and beyond may develop better adjustment patterns than those who never thought of socializing with the people outside university environment. 
Psychological adjustment is a very serious issue and when not managed properly can bring about internal medical problems like hypertension, stroke and emotional instability (Odongo, 2009). Retiring lecturers are supposed to make necessary arrangement for the acceptable coping strategies like not reacting extremely to shocks and traumas. When the retirees do not put into perceptive the likely offensive relationship that may emanate from the family because of too much closeness with them, they may likely die early.

The three different forms of retirement that exist in the work places are the voluntary, compulsory and mandatory retirement, which the Pension Commission (PenCom) objectives seem to guide at retirement for smooth transition. The Socio-Technical System theory was postulated by Fred Emergy in 1960 (Kpee, 2015). Emergy's Socio-Technical System theory centred on the premise that the success and non-success of an organization performance is caused by the interaction of social and technical factors. Such interactions are options of both linear and nonlinear complex event of unpredictable relationship. Kpee (2015) and Peretomode (2014) had rightly stated that, once the social and technical elements are put to work; an interaction must take place, and this will influence the performance of the organization.

The optimization of this interaction between socio and technical event tends to increase the quality of unpredictable performance of the organization toward objectivism and efficiency. The researchers are concerned with management practice on organizational effectiveness of welfare and retirement. The social exchange theory is a behavioural theory developed from two theoretical bases Kpee (2015). Thorndike 1932 and Mill 1923 cited in Kpee (2015), first developed the enforcement theory and the marginal utility theory.

According to (Cherry in Kpee, 2015:16) social exchange theory shows the social behaviour resulting from exchange process aimed at maximizing benefits and minimizing costs. To Cherry, people usually weigh the potential benefits and the possible risks for decision to take place in a social relationship this gave birth to the social exchange theory. This theory holds that in any social organization such as the university where there is an employer and employee relationship, choices are made to guarantee life security. This theory is relevant to the study, as the study sought to properly state of social security. The theory underline flexibility and economic reasoning in taking decision that will affect both management and line staffs who will later be retirees in due course. Social exchange and maximizing benefit are all attributes of social security hence its relevance.

Akinade (2009) however identified three types of retirement namely, self or voluntary, compulsory and mandatory. Voluntary/early-retirement means retirement that is caused by the individual or employee. Early or voluntary retirement could be by pressure from family members, friends, community, self-poor schedule or poor motivation can also cause voluntary retirement (Miller, 2007). Frustration and absence of motivation of an employer are also factors associated with voluntary retirement. Any retirement based on the employee's decision is voluntary and early. Voluntary or early retirement means, the employee may still get back since he/she is still energetic and so can be very useful to him or herself.

Compulsory retirement means forced withdrawal of an employee from service of an organization. It is not the personal will of the employee to withdraw from service. It gives no room for preparation apart from the employee's long service (Ahmed, 2013).Some of the reasons for compulsory retirement include old age, poor health, dwindling performance, inadequate or/and poor entry qualification, availability of qualified energetic youths, re- 
organization or an enterprise economic recess or crisis, poor work records and employer's deliberation decision.

A worker's lack of loyalty, rudeness insubordination and gross indiscipline can cause compulsory retirement. An employee could be retired because of physical inability, retardation, and lack of prerequisite qualification or criminal record. In Nigeria military, the appointments of junior officers to sensitive positions result to compulsory retirement of all his/her superiors. Mandatory retirement often occurs in organization or establishment where a standard is spelt out as prerequisite for retirement at entry point. The person could be asked to retire if he attains the age set out at entry. This class of retirement is statutory and compulsory, where an employee has served the required number of years in service for the employer and not yet the age of retirement, but he/she is retired from service. Anything mandatory is compulsory by law; this class of retirement is no longer applicable to universities' lecturers by the 2012 miscellaneous provision Act and Justices of the judiciary (https://www.pencom.gov.ng, 2017)

In the public service like the police force, military; civil service and other forms of work, retirement is classified into mandatory and grounds of age, anyone that comes first, the employee shall proceed on retirement. Under the mandatory retirement, the Public Service Rule (2008) states that, an employee shall serve for thirty-five (35) years or attaining the age of sixty (60) years before he/she proceed on retirement. It is in this regard that Eme and Ugwu, (2011) see mandatory retirement as externally imposed by the authority which may consider that continuing in office by the individual is no longer in the best interest of the service.

Barisi (2011), investigated correlates of psycho-social adjustment of retirees in Delta State. The study adopted correlational research design. Four research questions and four corresponding hypotheses were used to guide the study. A sample of 98 retirees was drawn through purposive sampling technique and used for the study. Pearson product moment correlation was used for the data analysis. It was found that, there is a significant relationship between the psychological wellbeing and psycho-social adjustment of retirees. It was recommended among others that, provisions should always be made on ways of managing retirees psychological state during active service.

Ahmed (2013) carried out a study on factors responsible for post-retirement life of retirees in Lagos state. The study adopted descriptive survey design and was guided by two research questions and three hypotheses. A sample of 100 retirees was drawn through accidental sampling technique. Mean standard deviation and independent t-test was used for data analysis. It was found that lack of pre-retirement plan is one of the factors responsible for poor post-retirement life of retirees. It was recommended among others that; adequate preretirement plans that will curtail the psychological problem associated with retirement should be well made during active service.

Danbajor (2009) investigated forms of pre-retirement plans among civil servants in Delta State. Descriptive survey research design was adopted for the study. Three research questions and two hypotheses were used to guide the study. A sample of 289 senior civil servants was drawn through accidental random sampling technique. Mean standard deviation and independent t-test was used for the analysis of data collected. It was found that, social wellbeing of retirees is one of the pre-retirement plans of civil servants. It was recommended that, proper pre-retirement plans will help retiree achieve a suitable social well-being. 
Kelih (2006) carried out a study on the relationship between psycho-social factors and retirees social adjustment in Rivers State. The study adopted correlational research design and was guided by three research questions and three corresponding hypotheses. A sample of 86 retirees were drawn through purposive sampling technique and used for the study. Instruments titled "Psycho-Social Factors Scale" (PSFS) and "Retirees Social Adjustment Scale" (RSAS) used for the data correlation was used to answer the research questions while their corresponding hypotheses were tested at 0.05 alpha level of significance.

It was found that, there is meaningful relationship between social factors and retirees social adjustment. It was recommended among others that retirees should always make conscious efforts in preparing themselves to over-come social problems associated with retirement.

Okoli (2012) investigated relationship between social-demographic variables and retirees stability. The study found that, there is no relationship between social factors and retirees stability in the society.

\section{Statement of the Problem}

From the background and literature, retirement is a point of rest, but the worrisome scenario is because their retirement benefits such as gratuity and pension are not paid to them by the government long after they retire from active work. The delayed and sometimes unpaid retirement benefits have a lot of implications on social and psychological problems of the retirees and his family members. Some lecturers even find it difficult to adjust to present realities after retirement. Majority of them begin to develop one health challenge or the other because of financial pressure and not being able to do active work. In the universities in Rivers State, statistics has shown that many retired lecturers die after a few years of retirement. This unsatisfactory state seems to reduce the chances of mentoring the upcoming lecturers by the experienced retired intellectuals. The researchers were worried by this and therefore investigated whether university lecturers have psychological and social pre-retirement plan as they discharge their statutory duties in the universities.

\section{Aim and Objectives}

The aim of this study was to determine the psychological and social pre-retirement plans of lecturers in the public universities in Rivers State, Nigeria. Specifically, the study sought to: Unravel the psychological pre-retirement plans of lecturers in the public universities in Rivers State, Nigeria. Fathom the social pre-retirement plans of lecturers in the public universities in Rivers State, Nigeria.

\section{Research Questions}

The following research questions were answered in this study.

1. What are the psychological pre-retirement plans of lecturers in the public universities in Rivers State, Nigeria?

2. What are the social pre-retirement plans of lecturers in the public universities in Rivers State, Nigeria?

\section{Hypotheses}

The following hypotheses were tested in this study at 0.05 level of significance.

1. There is no significant difference between the perception of science and arts lecturers on psychological pre-retirement plans in the public universities in Rivers State, Nigeria.

2. There is no significant difference between the perception of experienced and less experienced lecturers on social pre-retirement plans in the public universities in Rivers State, Nigeria. 


\section{METHODOLOGY}

This study adopted the descriptive research design. The population of the study comprised of 2330 lecturers in the 3 public universities in Rivers State. As at the time of this study, the population of lecturers in University of Port Harcourt (UNIPORT) was 1500, Rivers State University (RSU) 556 and Ignatius Ajuru University of Education (IAUE) 274. The sample size of the study was 932 lecturers which were drawn using proportionate stratified sampling technique of $40 \%$ from each of the universities' population. The instrument used for data collection was Lecturers Pre-Retirement Plan Scale (LPRS). Simple percentage was used to answer the research questions while the Chi-Square was used to test the null hypotheses at 0.05 alpha levels.

The accepted average percentage was 50\%. This means that any response below 50\% was not accepted by lecturers as their pre-retirement plans while any response from $50 \%$ above was agreed by lecturers as their retirement plans.

\section{Research Question One}

\section{RESULTS}

What are the psychological pre-retirement plans of lecturers in public universities in Rivers State, Nigeria?

Table 1: Percentage representation on the psychological pre-retirement plans of lecturers

\begin{tabular}{|c|c|c|c|c|c|}
\hline \multirow[t]{2}{*}{$\mathbf{S} / \mathbf{N}$} & \multirow[t]{2}{*}{ Psychological adjustment questionnaire } & \multicolumn{2}{|l|}{$\mathbf{A}$} & \multicolumn{2}{|l|}{ D } \\
\hline & & Freq. & $\% A$ & Freq. & $\% \mathrm{D}$ \\
\hline 7 & $\begin{array}{l}\text { I have made up my mind to start retirement in } \\
\text { good faith }\end{array}$ & 559 & $59.9 \%$ & 373 & $40.1 \%$ \\
\hline 8 & I have positive disposition towards retirement & 810 & $86.9 \%$ & 122 & $13.1 \%$ \\
\hline 9 & $\begin{array}{l}\text { I have already developed emotional stability } \\
\text { towards retirement }\end{array}$ & 622 & $66.7 \%$ & 310 & $33.3 \%$ \\
\hline 10 & I do not have any fear towards retirement & 534 & $57.3 \%$ & 398 & $42.7 \%$ \\
\hline 11 & I will be happy if I get to retirement age & 609 & $65.3 \%$ & 323 & $34.7 \%$ \\
\hline 12 & $\begin{array}{l}\text { I am not moved by retirement challenges my } \\
\text { retired colleagues face }\end{array}$ & 771 & $82.7 \%$ & 161 & $17.3 \%$ \\
\hline 13 & $\begin{array}{l}\text { I am encouraged when I remember that I will } \\
\text { retire someday }\end{array}$ & 691 & $74.1 \%$ & 241 & $25.9 \%$ \\
\hline \multirow[t]{3}{*}{14} & \multirow[t]{2}{*}{ Retirement is most desired as a civil servant } & \multirow[t]{2}{*}{588} & 63.1 & \multirow[t]{2}{*}{344} & $36.9 \%$ \\
\hline & & & 556 & & 213 \\
\hline & Grand percentage & & $69.5 \%$ & & $26.6 \%$ \\
\hline
\end{tabular}

Table 1 revealed that items with serial numbers $7,8,9,10,11,12,14 \& 14$ are the lecturers' psychological pre-retirement plans judging by the acceptable average percentage of $50 \%$ and above. However, the grand percentage of $69.5 \%$ showed that the lecturers agree that they have social pre-retirement plans while $26.6 \%$ have no social pre-retirement plans. Lecturers agreed that they have made up their minds to start retirement in good mood, have positive disposition towards retirement, have already developed emotional stability towards retirement, do not have any fear towards retirement, will be happy if they will get to retirement age not moved by retirement challenges faced by retired colleagues, encouraged when they remember that they will retire someday and that retirement is desired as civil servants. See figure 1 


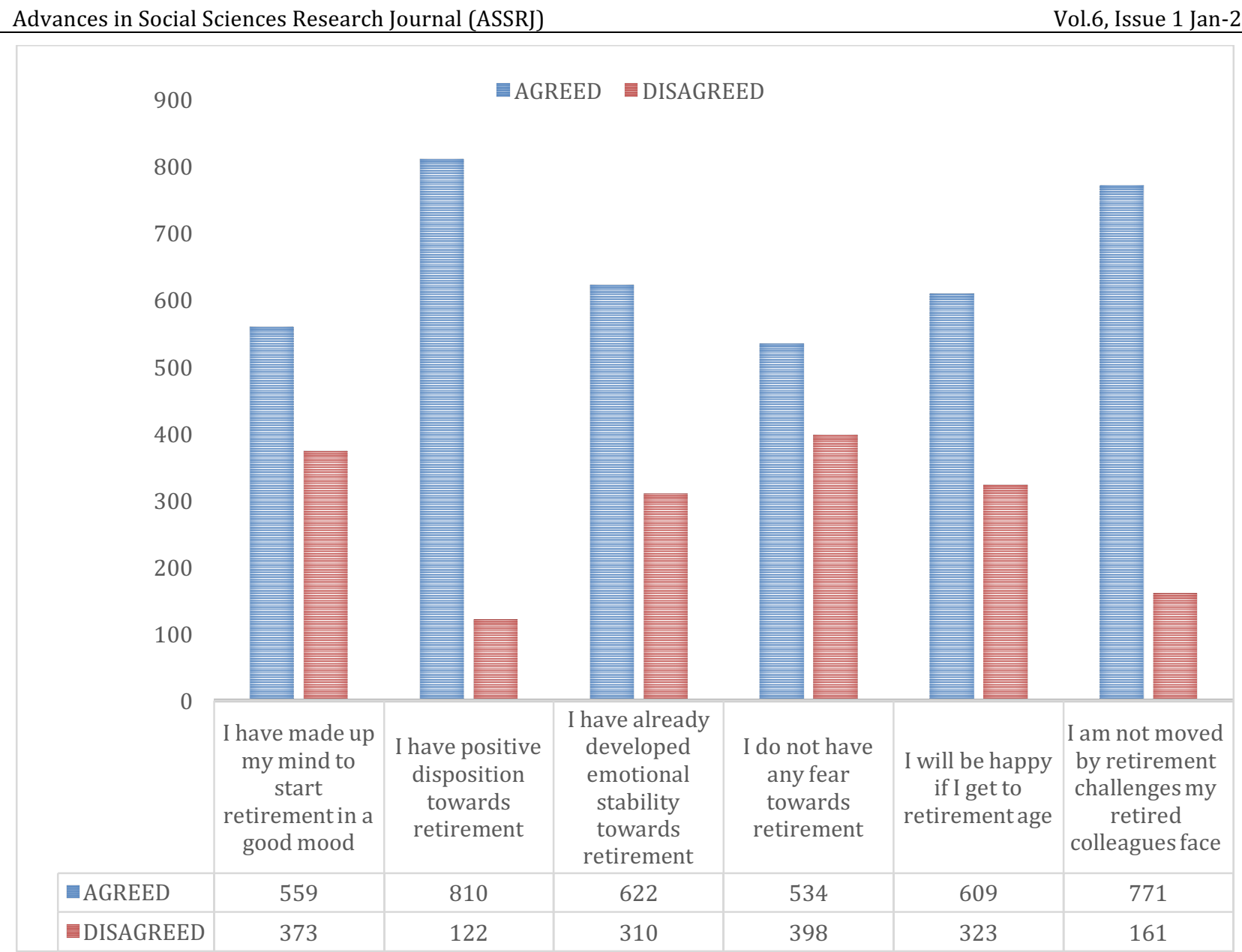

Figure 1: Graphical Representation of Psychological Pre-Retirement Plans of lecturers

\section{Research Question Two}

What are the social pre-retirement plans of lecturers in public universities in Rivers State, Nigeria?

Table 2: Percentage representation on the social pre-retirement plans of lecturers

\begin{tabular}{|c|c|c|c|c|c|}
\hline \multirow[t]{2}{*}{$\mathbf{S} / \mathbf{N}$} & \multirow[t]{2}{*}{ Social Pre-Retirement Plan } & \multicolumn{2}{|l|}{ A } & \multicolumn{2}{|l|}{ D } \\
\hline & & Freq & $\% A$ & Freq & $\% D$ \\
\hline 1 & $\begin{array}{l}\text { I will be involved in religious programs to } \\
\text { keep myself busy }\end{array}$ & 701 & $75.2 \%$ & 231 & $24.8 \%$ \\
\hline 2 & $\begin{array}{l}\text { I will involve myself with community } \\
\text { meetings }\end{array}$ & 211 & $22.6 \%$ & 721 & $77.4 \%$ \\
\hline 3 & $\begin{array}{l}\text { I will be hanging out with my friends all the } \\
\text { time }\end{array}$ & 118 & $12.7 \%$ & 814 & $87.3 \%$ \\
\hline 4 & I will be going to clubs after retirement & 207 & $22.2 \%$ & 725 & $77.8 \%$ \\
\hline 5 & $\begin{array}{l}\text { I will travel outside the country as soon as I } \\
\text { retire }\end{array}$ & 272 & $29.2 \%$ & 660 & $70.8 \%$ \\
\hline \multirow[t]{3}{*}{6} & $\begin{array}{l}\text { I will be an active member of a club that } \\
\text { engages in sporting activities }\end{array}$ & 786 & $84.3 \%$ & 146 & $15.7 \%$ \\
\hline & & & 246.2 & & 354 \\
\hline & Grand mean & & $41 \%$ & & $59 \%$ \\
\hline
\end{tabular}

\section{Legend: Agree (A), Disagree (D)}

Table 2 revealed that items with serial numbers $1 \& 6$ are the lecturers' social pre-retirement plans while items with serial numbers $2,3,4, \& 5$ are not part of lecturers' social retirement plans judging by the average acceptable percentage of $50 \%$. However, the grand percentage of 
$41 \%$ showed that the lecturers agree that they have social pre-retirement plans while $59 \%$ have no social pre-retirement plans. Lecturers agree that they will be involved in religious programs and that they will be active members of clubs that engage in sporting activities. See figure 2 for details.

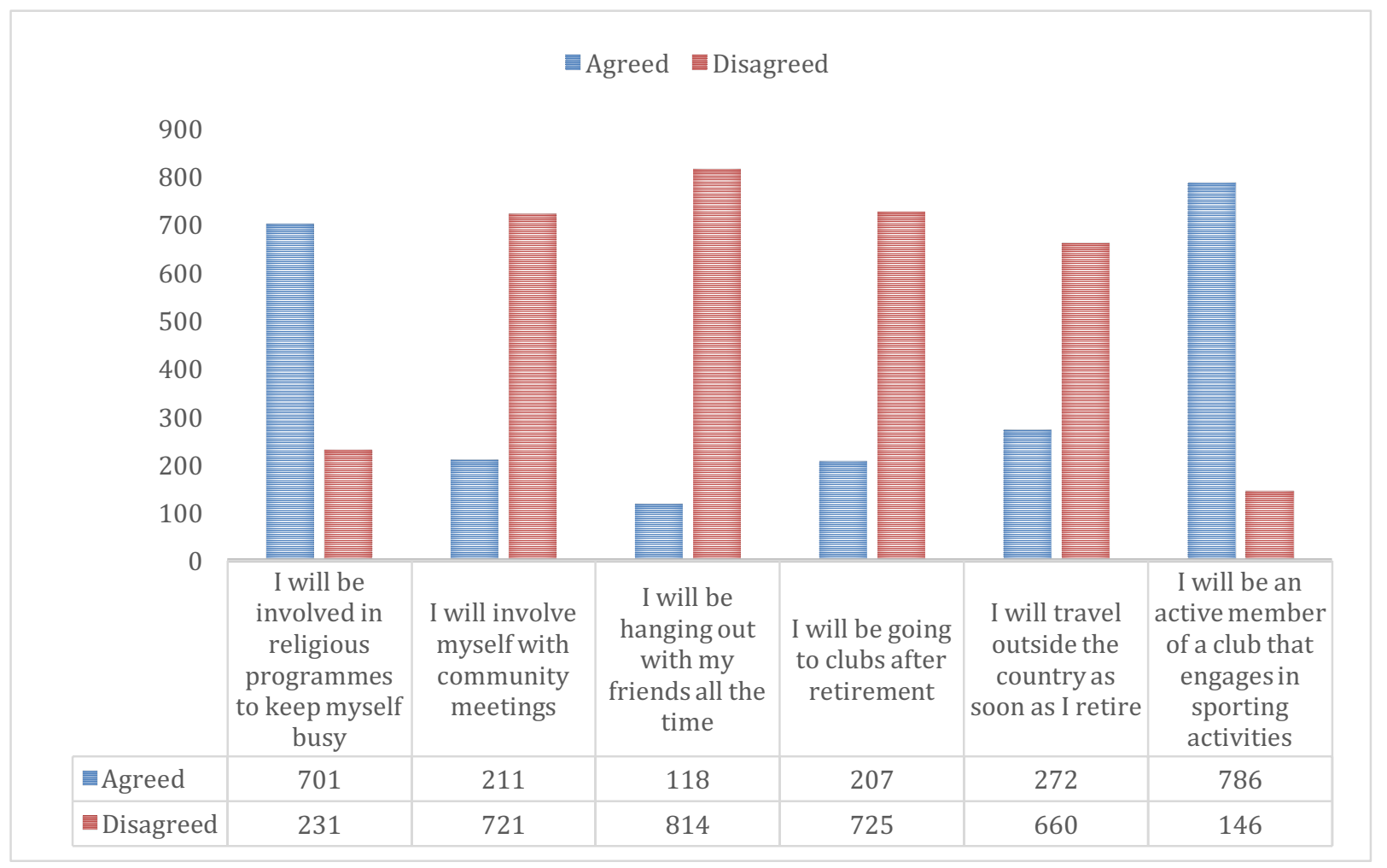

Figure 2: Frequency Representation of Social Pre-Retirement Plans of lecturers

\section{Hypothesis One}

There is no significant difference between the perception of science and arts lecturers on psychological pre-retirement plans in the public universities in Rivers State, Nigeria.

Table 3: Chi-Square $\mathrm{X}^{2}$ calculation on the difference between the number of lecturers that agree or disagree on psychological pre-retirement plans

\begin{tabular}{lccccc}
\hline Categories & N & Df. & $\mathbf{X}^{2}$ cal & Crit. value & Decision \\
\hline Science lecturers & 528 & 1 & 8.43 & 3.84 & Ho \\
& & & & \\
Arts lecturesected & 404 & & & \\
Total & 932 & & & & \\
\hline
\end{tabular}

Table 3 showed that with a degree of freedom of 1 and 932, the calculated $\mathrm{X}^{2}$ value of 8.43 is greater than the critical table value of 3.84. Therefore, the null hypothesis is rejected. By implication, there is a significant difference between the perception of science and arts lecturers on psychological pre-retirement plans in the public universities in Rivers State, Nigeria. 


\section{Hypothesis Two}

There is no significant difference between the perceptions of experienced and less experienced lecturers on social pre-retirement plans in the public universities in Rivers State, Nigeria.

Table 4: Chi-Square $X^{2}$ calculation on the difference between the number of lecturers that agree or disagree on social pre-retirement plans

\begin{tabular}{lccccc}
\hline Categories & N & Df. & $\mathbf{X}^{2}$ Cal & Crit. value & Decision \\
\hline $\begin{array}{l}\text { Experienced } \\
\text { lecturers }\end{array}$ & 602 & 1 & 0.17 & 3.84 & $\begin{array}{l}\text { Ho failed to } \\
\text { be Rejected }\end{array}$ \\
$\begin{array}{l}\text { Less } \\
\text { experienced }\end{array}$ & 330 & & & & \\
$\begin{array}{l}\text { Lecturers } \\
\text { Total }\end{array}$ & & & & & \\
\hline
\end{tabular}

Table 4 showed that with a degree of freedom of 1 and 932, the calculated $X^{2}$ value of 0.17 is less than the critical table value of 3.84. Therefore, the null hypothesis is accepted. By implication, there is no significant difference between the perceptions of experienced and less experienced lecturers on social pre-retirement plans in the public universities in Rivers State, Nigeria.

\section{DISCUSSION OF FINDINGS}

The grand percentage of $41 \%$ showed that $41 \%$ of the lecturers agree that they have social preretirement plans while 59\% said they have no social pre-retirement plans. Specifically, lecturers agreed that they will be involved in religious programs and the lecturers said that they will be active members of clubs that engages in sporting activities. The $41 \%$ of these lecturers showed that fewer number of them (minority) have social pre-retirement plans.

The fact that majority of the lecturers do not have social pre-retirement plans disagrees with Danbajor (2009) when he investigated forms of pre-retirement plans among civil servants in Delta State. Danbajor found that the social wellbeing of retirees is one of the pre-retirement plans of civil servants. The pre-retirement plan of lecturers when properly taken into consideration can bring about stability of workers after active work life. This assertion disagrees with Okoli (2012) who found that there is no relationship between social factors and retirees' stability in the society. Kelih (2006) found there is a meaningful relationship between social factors and retirees social adjustment.

This shows that social involvement is very important for smooth transition into social wellbeing in the society. There is no significant difference between the perceptions of experienced and less experienced lecturers on social pre-retirement plans in the public universities in Rivers State, Nigeria. There is a significant difference between the perception of science and arts lecturers on social pre-retirement plans in the public universities in Rivers State, Nigeria.

The difference in the perceptions of the lecturers could stem from the fact that they are from different areas of specializations and may be consulted in different dimensions. This difference could be linked to the level of social inclinations among the Science and Arts lecturers. Hence this study concurred with the finding of Kelih (2006). 


\section{LECTURERS' PSYCHOLOGICAL PRE-RETIREMENT PLANS}

The grand percentage of $69.5 \%$ showed that (majority) of the lecturers agree that they have psychological pre-retirement plans while $26.6 \%$ (minority) have no psychological preretirement plans. Specifically, lecturers agreed that they have made up their mind to start retirement in good mood, some said they have positive disposition towards retirement, some of the lecturers said they have already developed emotional stability towards retirement, do not have any fear towards retirement, some of the lecturers said they will be happy if they will get to retirement, some of the lecturers said they are not moved by retirement challenges faced by retired colleagues, that are encouraged when they remember that they will someday retire and retirement is most desired as civil servants.

The findings of this study are in line with the finding of Barisi (2011) who found that lecturers do not experience a lot of psychological problems upon retirement because of the number of experiences acquired on the job. This is a fact because lecturers tend to make friends with colleagues and students who may have shared one experience or the other with them in their life and how they were able to wriggle out of such scenario. The relationship established with colleagues during active service may have made some lecturers to develop coping strategies with the challenges outside. There is a significant difference between the perception of Science and Arts lecturers on psychological pre-retirement plans in the public universities in Rivers State, Nigeria. The finding of this study is in line with the finding of Barisi (2011) who found that there is a meaningful relationship between the psychological wellbeing and psycho-social adjustment of retirees. The significant difference between the Science and Arts lecturers is traceable to the fact that they have different orientations that make them adjust psychologically.

The Science lecturers are more in the laboratory doing experiments with inanimate objects most of the time and plants hence not having enough time to share their problems with other people. This may make them have emotional challenges that can affect their mood even after retirement because they were unable to learn from other peoples experience during active service.

\section{It can be established that:}

\section{CONCLUSION}

The grand percentage of $41 \%$ showed that the lecturers agree that they have social preretirement plans while 59\% have no social pre-retirement plans. Lecturers agree that they will be involved in religious programs and that they will be active members of a club that engages in sporting activities. There is no significant difference between the perceptions of experienced and less experienced lecturers on social pre-retirement plans in the public universities in Rivers State, Nigeria.

The grand percentage of $69.5 \%$ showed that the lecturers agree that they have psychological pre-retirement plans while $26.6 \%$ have no psychological pre-retirement plans. Lecturers agreed that they have made up their mind to start retirement in good mood, have positive disposition towards retirement, have already developed emotional stability towards retirement, do not have any fear towards retirement, will be happy if they will get to retirement, not moved by retirement challenges faced by retired colleagues, encouraged when they remembered that they will someday retire and retirement is most desired as a civil servant.

There is a significant difference between the perceptions of science and arts lecturers on psychological pre-retirement plans in the public universities in Rivers State, Nigeria. 
Based on the findings, it was concluded that lecturers' do not make adequate preparation on pre-retirement plans in the areas of social and psychological.

\section{RECOMMENDATIONS}

Based on the findings of this study it was recommended that:

1. Lecturers should endeavour to belong to professional organization in their areas of specialization and in the society where they live in order to cope effectively through socialization.

2. Pre-Retirement Guidance Counselling Centres should be established in the university communities where lecturers who have emotional problems can go and seek help from counsellors.

3. Motivational speakers with special concepts on human psychology should be invited to give lectures during ASUU meetings to sensitizes/educate lecturers on life after retirement.

\section{References}

Ahmed, M. (2013). Factors responsible for poor post-retirement life of retirees in Lagos State. Unpublished B. Sc Project of Lagos State University.

Akinade, E.A. (2009). Towards satisfactory retirement; a socio psychological approach. Nigeria: Kola Okan Lawson services limited.

Barisi, I.J. (2011). Correlates of psycho-social adjustment of retirees in Delta State. Journal of Contemporary Research 6 (4), 43-56.

Danbajor, O. (2009). Forms of pre-retirement plans among civil servants in Delta State. Unpublished Thesis of Delta State University, Abaraka.

Eme, O.I. \& Ugwu, S.C. (2011). The laws and administration of retirement in Nigeria: A historical approach. In Kuwait chapter of Arabian Journal of Business and Management Review. 1(2); 1-10.

Federal Republic of Nigeria (2008). Public Service Rules. Abuja: Federal Government Printer.

Kelih, C. (2006). Relationship between psycho-social factors and retirees social adjustment in Rivers State. Journal of Education. 2 (1), 14-26.

Kpee, G.G. (2014). Theories and theoretical frameworks: The researchers' handbook. Owerri: Uzopietro Publisher.

Miller, M.C. (2007). Pre-retirement plans and teachers job performance in Lagos State. Journal of Science Education 3 (2), 22-36.

Okoli, N.S. (2012) Relationship between social-demographic variables and retirees Stability. Journal of MultiDisciplinary Research. 1 (1), 23-37.

Odongo I. (2009). Head, Internal Medicine. 1.2 Referral of a child with a medical problem

Peretomode, V.F. (2014). Theories of management, implication for educational administration. Abraka, University Printing Press.

(https://www.pencom.gov.ng, 2017) 